\title{
DEVELOPMENT A LOCAL SYSTEM FOR MEASURING TRACTORS PERFORMANCE
}

\author{
Samir M. Younis* ${ }^{* *} \quad$ ， EL. Said R. Elashry*, \\ Ahmed. F. Bahnasy ${ }^{* *} \quad$ Islam. M., Elsybaee*
}

\begin{abstract}
The tractor test systems were conducted to evaluate the effect of the modified system and compared to the system used in tractor test station on the value of tractor performance. The developed device is consisted of transducer, signal conditioner and recorded unit. The hydraulic pull dynamometer, strain gage pull dynamometer, load cell, hydraulic PTO dynamometer, magnetic pickup transducers and fifth wheel were used to measure tractor parameter. Statically analysis shows that no significant between devolved device (named system 1) and the system used in tractor test station (named system2). Devolved device is expected to be a worthy one to establish reliable data of the performance parameters of tractors and implements.
\end{abstract}

\section{INTRODUCTION}

The proper selection of tractor and implement for a particular farm
situation requires availability of the field performance data of both
tractors and implements. Tractor and implement test are needed in different farm sites under different operating conditions to prevent serious damage. This will enable the proper selection of tractor and implement for a particular requirement.

Many of instrumentation systems are determine the field performance of tractors and implements operating under different field conditions have been developed and reported by researchers. Most of them were designed exclusively for a particular tractor and not easily adaptable to other tractors. Also most of the developed systems were used to majority parameters like drawbar pull, ground speed, and drive wheel speed. From these measurements drawbar power and wheel slip could be calculated. This is hard and expensive to instrument one tractor and take it to

* Prof. of Agric. Eng. - Faculty of Agric.- Alexandria University.

**** Senior Researcher, Agric. Eng. Research Institute, Dokki, Giza, Egypt.

*** Engineer, Agric. Eng. Research Institute, Dokki, Giza, Egypt. 
different farm sites to make a complete field performance data bank for the tractors and implements. So it is necessary to have simple instrumentation system easily adaptable to a wide range of agricultural tractors used in different farm sites and if any part of the instrumentation system damaged it is necessary to find another part.

Raheman and Jha (2007) was developed a microcontroller-based slip sensor for a $2 \mathrm{WD}$ tractor to indicate slip values during on-farm use. This sensor comprised of four components: power supply; sensing of throttle position, gear position, and wheel rpm; processing of collected data; and display unit. Power was taken from the tractor battery. Rotary potentiometer and proximity switches were installed on the tractor to measure throttle position and wheel revolution, respectively. The performance of developed slip sensor was evaluated both on tar macadam surface as well as in the field. The variations between indicated and actual slip were found to be within $0-5 \%$ for both the surfaces, thus indicating the accuracy of slip measurement by the developed slip sensor.

Mohamed et al., (2004) designed and calibrate the drawbar pin which could be used as a force transducer to measure the draft of trailed implements. This pin transducer consists of a pin on which are mounted a total of four strain gauges. This pin is used as a hitch pin and as a measuring device without changing the tractor hitch configuration. Field experiments were carried out with disk harrow at different harrowing depths. The pin transducer producer a linear out put depend end of pull force only. (Nada, 2003; Elgwadi 2005) presented a direct method of estimating tractor power by measuring torque and numbers of revolutions of the tractor power take off shaft, during operating rotating agricultural implement at actual field work.

Miszczak (2005) mentioned that there were many models describing the work of rotary tillers, including torque valuation because the torque requirement may be very important for designers, as well as for other experts applying such machines in the field operations. Strain gage load devices convert the load acting on them into electrical signals. The gages themselves are bonded on to a structural member that deforms when weight is applied. In most cases, four strain gages are used to obtain maximum sensitivity and temperature compensation. Two of the gauges 
are usually in tension, two in compression and are wired with compensation adjustments. When weight or torque is applied, the strain changes the electrical resistance of the gages in proportion to the load or torque.

Elashry (2002) was used a separated apparatus for fuel consumption. It was installed and connected to tractor fuel tank through hoses and two 2way valves. The secondary tank was first filled with fuel to the mark on the tope of the tab. During the actual run, the tractor was first let go on its fuel from the main tank. To measure the fuel consumption during a specific field operation, the secondary tank was utilized through the valve (1) and (2).at the end of the run, the valves were refilled off. The secondary tank was refilled to the mark on the tube from a graduated cylinder and amount of refuel was taken as fuel consumption during the specific operation duration.

(Elashry et al., 1994; Al-Janobi et a., 1998; Nada, 2003) used the $5^{\text {th }}$ wheel to measure the travel speed, it is made from a motorcycle wheel and tire with a medium knobby tread. It is connected to the tractor via spring load 4-bar linkage.

Chen et al., (2007), developed a 2D double extended octagonal ring (DEOR) drawbar dynamometer with a draft capacity of $180 \mathrm{kN}$. The two extended octagonal rings were oriented vertically on either side of the tractor drawbar which provided a better match of strain to expected drawbar draft and vertical load than could be achieved with a horizontal orientation in previous designs.

Sahu and Raheman (2008) used A decision support system (DSS) was developed in Visual Basic 6.0 programming language for matching tillage implements with $2 \mathrm{WD}$ tractors and for predicting the field performance of the tractor-implement system. The DSS was validated with the data collected from the field experiments conducted with a $31 \mathrm{~kW}$ PTO power 2WD tractor and three tillage implements $(2-30 \mathrm{~cm}$ moldboard plow, 7-7 disks $(1.6 \mathrm{~m})$ offset-disk harrow and $9-23 \mathrm{~cm}$ field cultivator) under different soil and operating conditions. It was found that the DSS on an average under-predicted the draft and slip values by 10.2 and $15.6 \%$, respectively, while it over-predicted the actual field capacity by $2.5 \%$ from the observed values. 
The objectives of this search were to:

- Construct and calibrate local system simple and cheap to measure the field performance such as P.T.o torque, drawbar pull travel speed, fuel consumption and (fuel, oil and cooling) temperature.

- Designe strain gage pull dynamometer to measure tractor drawbar pull.

- Constructing load cell transducer to measure the vertical force which applied to the torque with PTO dynamometer arm.

\section{MATERIALS AND METHODS}

\section{Tractor test main elements}

Any measuring system should be consisting of necessary elements such as 1-transducer 2- signal conditioner 3- recorder or indicator.

\section{1- The transducer:}

The transducer is an energy converter which receives the physical quantity being measured and converts it in to some other physical variable; e.g. flow to pressure, speed to voltage, strain to resistance. The transducer is undoubted the weakest link in the measuring chain, for the measured quantity is always modified by the presence of the transducers, making a perfect measurement theoretically impossible. This" loading" effect can by minimized by the design and installation of the transducer, but it is always present to some degree.

\section{2-The signal conditioner:}

The signal conditioner rearranges the transuded signal to a form which can be readily recorded or monitored.

\section{3-The recorder or display:}

The recorder or display is the recorder, display, or indicating device. Many recorders have a transuding action at their followed by some further signal conditioning.

Tractor test measurements are fuel consumption, draft or drawbar pulls ground speed, fuel, oil and cool temperature and slip ratio.

\section{A-Fuel apparatus}

A separate apparatus was used to measure fuel consumption. It consisted of a secondary tank of 4.5 liters capacity with a level marked tube and bulb with volume $127.4 \mathrm{~cm}^{3}$.

\section{B-Strain gage pull dynamometer}


Strain gage pull dynamometer was designed and constructed at tractor test station. The objective of construction this drawbar force transducer is to measure the draft of the tractor under test on the concrete road and field test from which the power requirements can be determined. Basically the pull transducer was constructed by machining down a middle section of a G10180 (1.5 x1.9 cm) hot-rolled (HR) steel. The anticipate stresses were calculated for maximum tractor intended for this design which tractor is used. The transducer dimension was $(24 \times 1.9 \mathrm{~cm})$ and was machining down to $(1.5 \times 1.9 \mathrm{~cm})$ in cross section at the point where the gages are mounted. The strain gage pull dynamometer is illustrated in Figure (1).

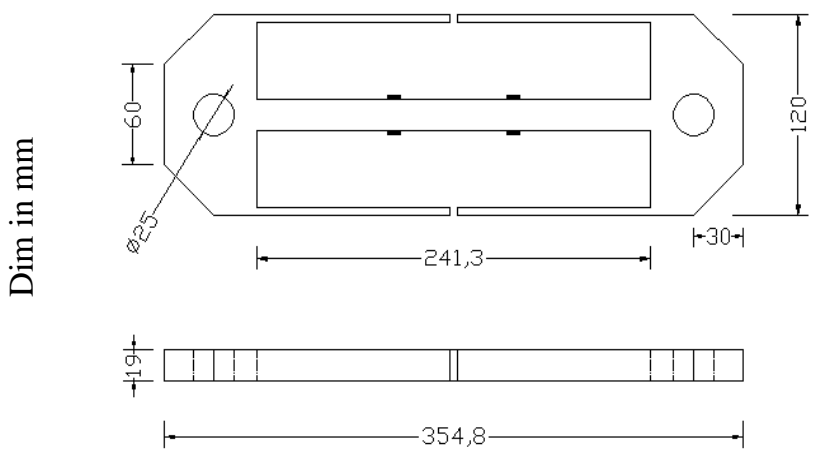

Figure (1): The strain gages pull dynamometer.

\section{C-Strain gage indicator}

The strain gage indicator is portable, battery powered precision instrument for use with resistive strain gages and transducers. The strain gage indicator accepts full, half, or quarter bridge.

\section{D-Modified System Description}

Construction of the developed device was installed at the Testing and Research Station for Tractors and Farm Machinery, Alexandria Governorate. The modified system had stages and a lot of components .it is consist of amplifier circuit, digital multimeter and computer. Modified system used to measure drawbar pull, PTO torque, rotational speed, ground speed, oil temperature, cooling temperature and fuel temperature.

\section{E-Strain gage load cell}

The objective of constructing this load cell transducer is to measure the vertical force which applied to do torque with PTO dynamometer arm from which the power requirements can be determined basically the load 
cell was constructed by machining down of middle section of a G10180 $(20$ $\mathrm{mm}$

$11 \mathrm{~mm}$ ) hot-rolled (HR) steel the anticipation stresses were calculated for maximum tractor intended for this design. The transducer dimension was $15.5 \mathrm{~cm} \times 8 \mathrm{~cm}$ and was machined down to $(20 \mathrm{~mm} \times 11 \mathrm{~mm})$ in cross section at the point where the gages are mounted. The strain -gage load cell design is illustrated in Figure (2).
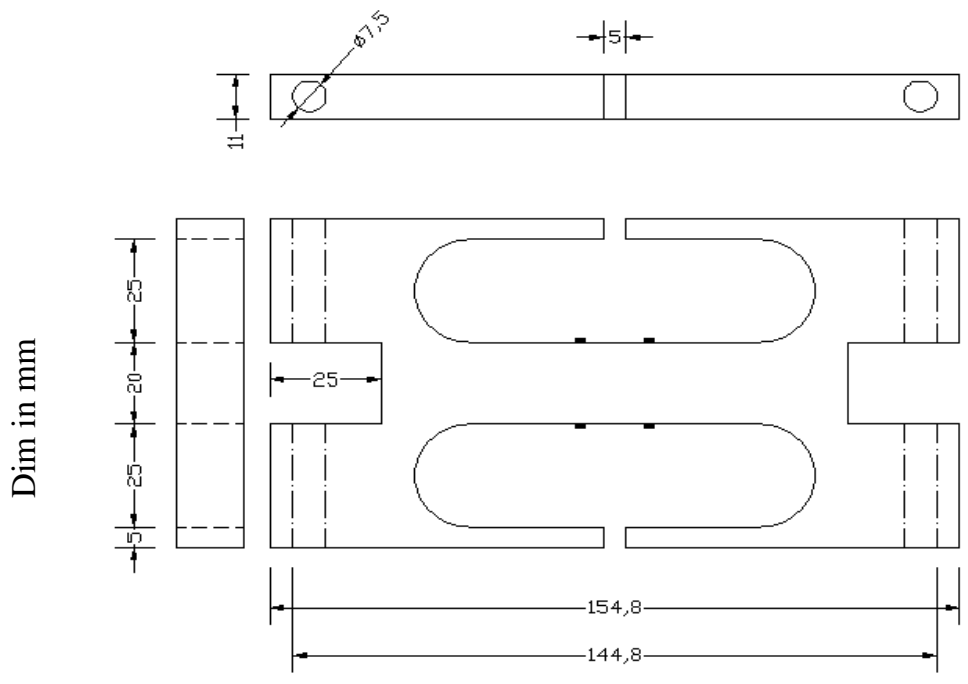

Figure (2): The strain gage load cell

\section{F-Hydraulic drawbar dynamometer.}

For agricultural work hydraulic drawbar dynamometer are widely used. The pressure set up in the fluid contained in a hydraulic link is transmitted to a small recording cylinder, in which a plunger acts against the force of a spring. The movement of the plunger may be read directly, the hydraulic drawbar dynamometer was used to calibrate the strain gage pull dynamometer. The hydraulic drawbar dynamometer capacity is $8000 \mathrm{~kg}$. Its indicator was analog but it had liquid in his indicator box to reduce the movement of the indicator when any one wants to read any values.

\section{Specifications of tractors}

Three tractors used in this study and numbered from 1 to 3 . Tractors No (1) and (2) were used as loading tractors the other was used for testing the instrumented trailed under study. The three tractors specifications are tabulated in Table (1). 
Table (1): Specifications of tractors

\begin{tabular}{|c|c|c|c|}
\hline specifications & Tractor No(1) & Tractor No(2) & Tractor No(3) \\
\hline Make & U.S.A & U.S.A & --------------------- \\
\hline Model & John Deere & John Deere & ---------------------- \\
\hline $\begin{array}{l}\text { Number of } \\
\text { driving wheel }\end{array}$ & $4 \times 4$ & $4 \times 4$ & $4 \times 4$ \\
\hline \multicolumn{4}{|c|}{ Engine } \\
\hline Model & 6076 TRWO4 & 6076 TRW08 & ---------------------- \\
\hline Type & Diesel & Diesel & Diesel \\
\hline Cylinders & 6 (Vertical) & 6 (Vertical) & 6 (Vertical) \\
\hline Bore $\mathrm{x}$ stroke & $115.8 \times 120.7$ & $115.8 \times 120.7$ & \\
\hline Cubic capacity & $7634 \mathrm{cc}$ & $7634 \mathrm{cc}$ & $7500 \mathrm{cc}$ \\
\hline \multicolumn{4}{|c|}{ Fuel system } \\
\hline Feed system & In-line & In-line & In-line \\
\hline $\begin{array}{l}\text { Fuel tank } \\
\text { capacity }\end{array}$ & 246 liters & 246 liters & 220 liters \\
\hline $\begin{array}{l}\text { Rated engine } \\
\text { Power }\end{array}$ & $88 \mathrm{~kW}$ at $2200 \mathrm{rpm}$ & $80 \mathrm{~kW}$ at $2200 \mathrm{rpm}$ & $\begin{array}{l}120 \mathrm{~kW} \text { at } 2100 \\
\mathrm{rpm}\end{array}$ \\
\hline \multicolumn{4}{|c|}{ Cooling system } \\
\hline Type of coolant & Water & Water & Water \\
\hline \multicolumn{4}{|c|}{ Power take off } \\
\hline Type & Independent & Independent & Independent \\
\hline Actuation & $\begin{array}{l}\text { Electro hydraulic, } \\
\text { gradual, operator } \\
\text { controlled }\end{array}$ & $\begin{array}{l}\text { Electro hydraulic, } \\
\text { gradual, operator } \\
\text { controlled }\end{array}$ & $\begin{array}{l}\text { Electro hydraulic, } \\
\text { gradual, operator } \\
\text { controlled }\end{array}$ \\
\hline Speed & $540 / 1000 \mathrm{rpm}$ & $540 / 1000 \mathrm{rpm}$ & $540 / 1000 \mathrm{rpm}$ \\
\hline \multicolumn{4}{|c|}{$\begin{array}{c}\text { Tractor Dimensions } \\
\end{array}$} \\
\hline Length (mm) & 4023 & 4027 & 4266 \\
\hline Width $(\mathrm{mm})$ & 2438 & 2870 & 2523 \\
\hline Height $(\mathrm{mm})$ & 2959 & 3173 & 2989 \\
\hline Wheel base & 2676 & 2675 & 2723 \\
\hline \multicolumn{4}{|c|}{ Tractor weight } \\
\hline Total $(\mathrm{kg})$ & 6415 & 6329 & 6300 \\
\hline
\end{tabular}

\section{Measurement}

The measurements required to determine tractor performance are fuel consumption, drawbar pull, PTO torque, ground speed, rotational speed, slip and (fuel, oil and cool temperature).

\section{1-Fuel consumption}

A separate apparatus was used to measure fuel consumption. It consisted of a secondary tank of 4.5 liters capacity with a level marked tube and bulb with volume $127.4 \mathrm{~cm} 3$. The apparatus was installed and connected to the tractor fuel Tank through hoses and two valves. The secondary tank was first filled with fuel during the actual run. The tractor was first let go 
on its fuel from the main tank to measure the fuel consumption during a specific field operation, the secondary tank was utilized through the valves to fill the bulb. Then, turn the valves off and used stop watch when the fuel arrived to the first mark of the bulb. After that when the fuel arrives to the second mark. Turn off the stop watch at the same time. The bulb had constant volume, so it's easy to calculate the fuel consumption. this system used to measuring fuel consumption with the nine gears when measured the drawbar power and measuring fuel consumption at PTO power.

\section{2-Drawbar pull}

Two methods used to measure the drawbar pull. Drawbar pull measured using strain gage pull dynamometer. The calibrated hydraulic dynamometer (5 ton capacity) at faculty of engineering Alexandria University was to calibrate the pull meter strain gage. The strain gage pull meter was connected with new instrument or strain indicator to calibrate the strain gage pull meter. An applied in equal steps from no load to the maximum allowed load and then reduced load approximately in the same steps back to no load.

\section{3-Tractor PTO torque}

The PTO hydraulic dynamometer used to measure the PTO torque and PTO (r.p.m) to determine PTO power. Two methods used to measure the PTO torque.

First method the developed used device with load cell used to measure the torque. A known torque was applied to the transducers. The value of the known load was read with new instrument. A known torque was applied from no load to the maximum allowed torque. Load cell transducers were exited by a stabilized dc volt supply with input battery (9) volt the new instrument read the volt with the same torque. The second method the same procedures was followed with the strain meter.

\section{4- Ground speed}

Two methods used to measure the ground speed, using fifth wheel and the traditional method. The first method is the true ground speed is measured using a 5th wheel. It mounted on a tool bar directly behind the right front wheel. The fifth wheel can be positioned on the tool bar so that it either follows in the track made by the front tractor wheel or rolls on 
undisturbed soil. This flexibility is useful since on rough, bumpy ground it may be preferable to operate in the wheel track, but on smooth ground it may be better to run on undisturbed. The $5^{\text {th }}$ wheel was made from a motorcycle wheel and tire with a medium knobby tread. It is connected to the tractor via a spring load 4-bar linkage. A magnetic pick-up mounted to the vertical bar senses the rotation of a toothed gear with 120 -tooth gear was attached to the $5^{\text {th }}$ wheel with this arrangement the magnetic pick-up can move vertically but cannot rotate as the $5^{\text {th }}$ wheel moves up must sense only $5^{\text {th }}$ wheel rotation. The signal comes from magnetic pickup goes directly to the modified system. Figure (3) shows the fifth wheel mechanism.

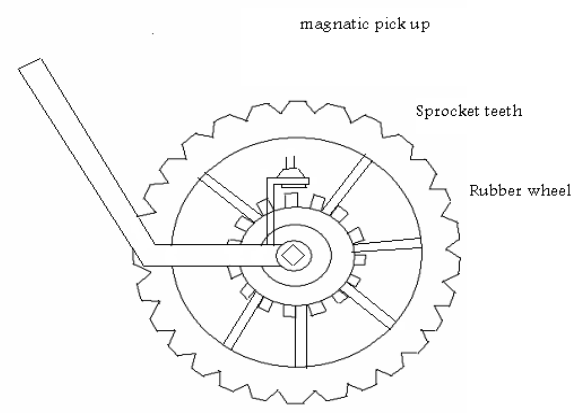

Figure (3): The fifth wheel mechanism

\section{5- P.T.O rotational speed}

The number of revolutions of land engaging wheels on tractors and machines test rigs and in the field and pedals and handles of machines such as small threshers, grinders and water pumps, can be counted by eye. For shafts turning at higher speeds, some form of counting apparatus is required. For high rotational speed there are two methods to measure it. The first method is mechanical revolution counters and totalizes will require time to be measured by stop watch. Electrical and electronic units automatically count the number of revolutions over a period of time and the results are displayed and continually updated. This unit used with PTO hydraulic dynamometer. The second method is used a new instrument with a magnetic pick up to calculate the number of revolution by calibrating the new instrument. The wheel speed transducer was illustrating in Figure (4). 


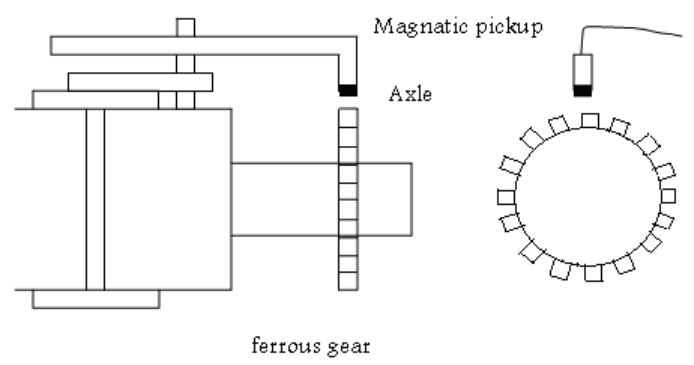

Figure (4): The rotational speed transducer

\section{6-Fuel, oil and cool temperatures}

The digital multimeter used to measure temperature. The DT92 Advanced series digital multimeter is a compact precision and battery operated.

\section{7- Slip ratio}

Slip is defined as the relative movement in the direction of travel at the traction device-soil interface. It is generally expressed as:

$$
\mathrm{S}=1-\frac{\mathrm{V}_{\mathrm{a}}}{\mathrm{V}_{\mathrm{t}}}
$$

Where:

$$
\begin{aligned}
\mathrm{S} & =\text { wheel slip }(-) \\
\mathrm{V}_{\mathrm{a}} & =\text { actual travel speed } \\
\mathrm{V}_{\mathrm{t}} & =\text { theoretical wheel speed }=\mathrm{r} \times \omega \\
\omega & =\text { angular velocity of wheel }(1 / \mathrm{sec}) \\
\mathrm{r} & =\text { actual rolling radius of wheel on hard surface }(\mathrm{m})
\end{aligned}
$$

A simple methods of determining the a mount of wheel slip is to make a mark on the tractor drive wheel with colored tapes and a known distance the tractor moves forward is measured, 10 revolution under no load (A) and on the same surface and with the same number of revolutions with load (B). Pins adequate length will used for making on the field.

Percentage of wheel slip $=\frac{A-B}{A} \times 100$

The calibration of the rational speed was made in the lab of tractor test station by applying a known rational speed in equal steps from no speed to the maximum allowed speed and then reduced in approximately the same steps back to no speed; sprocket with magnetic pickup was used, with 60 teeth. The sprocket was used to measure the RPM of the PTO of the tractor during the PTO test of the tractor. 
The following equation represent the calibration data.

$$
\mathrm{Y}=0.0008 \mathrm{X}+0.0667
$$

Where:

\section{Calibrations}

$$
\begin{aligned}
& \mathrm{Y}=\text { device reading } \mathrm{mv} \\
& \mathrm{X}=\text { Rotation speed, } \mathrm{rpm}
\end{aligned}
$$

\section{1- Strain gage pull dynamometer calibration}

The pull dynamometer was attached to a steel column which was fixed to a tractor. The calibrated hydraulic dynamometer was attached in series with the pull meter strain gage. The load was applied to the transducer using a pre-calibration unit; the pull meter was connected with new instrument and/ or strain indicator, the same procedure from no load to the maximum allowed load is followed. The calibration equation between hydraulic and strain gage dynamometer can be expressed as follows:

$$
\mathrm{Y}=0.2121 \mathrm{X}
$$

$\mathrm{Y}=$ value of strain gage dynamometer, $\mathrm{kN}$

$\mathrm{X}=$ Value of hydraulic dynamometer, $\mathrm{kN}$

\section{2- Calibrating the hydraulic (PTO) dynamometer}

1. Turn knob counter clockwise to open valve on hand pump to relive hydraulic pressure in recording cylinder.

2. Locate sliding button at 12 inch torque mark on torque arm bar. Position recording cylinder directly under sliding button and lock cylinder in place.

3. Position test bar torque arm. Align mark on test bar with 12 inch mark on scale of torque arm bar.

4. To charge recording cylinder. Close valve on hand pump. Then operate hand pump so that torque arm does not contact either torque arm stops.

5. Hang a known weight from the 4 foot mark near the end of the feet bar.

If adding weight causes torque arm to touch torque arm stop.

6. Read inner (kW) scale .Multiply reading by ten to obtain (N.m)

\section{3- Load cell calibration}

Torque was recoded with new instrument and/or strain indicator. A known torque was applied from no load to the maximum allowed torque and then reduced in approximately the same steps back to no load. Load cell transducers were exited by a stabilized dc volt supply with input 
battery (9) Volt the new instrument read the volt with the same torque and strain indicator read the torque with the same strain or $\mathrm{mV}$.

The following equation expressed the relationship between applied torque and the development instrument and strain meter device:

$$
\mathrm{Y}_{1}=0.3845 \mathrm{X}_{1}
$$

Where:-

$\mathrm{Y}_{1}=$ new instrument reading, $\mathrm{mv}$;

$\mathrm{X}_{1}=$ applied torque $\mathrm{kN}$

\section{4-Fifth wheel calibration}

The fifth wheel was calibrated at concrete road a known forward speed in equal steps from no speed to the maximum allowed speed, and then reduced in approximately the same steps back to no speed, with magnetic pickup with 120 tooth sprockets. The following equation represents the calibration data by using the fifth wheel.

$$
\mathrm{Y}=0.63 \mathrm{X}
$$

Where:

$$
\begin{aligned}
& \mathrm{Y}=\text { Device reading, } \mathrm{mv} \\
& \mathrm{X}=\text { Forward speed, } \mathrm{km} / \mathrm{hr}
\end{aligned}
$$

\section{RESULT AND DISCUTION}

\section{1- Drawbar performance test}

The governor control lever shall be sit for maximum power at rated engine speed. In case of part- time $4 \mathrm{WD}$, tests shall be performed under 4WD condition.

Drawbarpower $(\mathrm{kW})=\frac{\text { Drawbar pull }(\mathrm{N}) \times \text { traveling speed }(\mathrm{km} / \mathrm{hr})}{3600}$

The tests at the drawbar shall be conducted according to the following regulations in order to provide reasonably comparable results in all countries. For tractors with pneumatic tires, the tests shall be carried out on a clean, horizontal, dry concrete or tar macadam surface containing a minimum number of joints. Tests of steel -wheeled tractors and tracklaying tractors shall be carried out on flat, dry, horizontal, mown or grazed grassland, or on a horizontal track having equally good adhesion characteristics: A moving track (treadmill) may also be used subject to the conditions that results produced are comparable to those obtained on 
the surface mentioned above. The type of track test shall be clearly stated in the report.

\section{2-PTO performance test}

The PTO speed, torque and fuel consumption were recorded. Measuring was done on the steps starting from min engine speed to max engine speed. The shafts connecting the PTO to the dynamometer shall not have any appreciable angularity at the universal joint. The temperature of the atmosphere shall be $23 \pm 7^{\circ} \mathrm{c}$.

$$
\text { PTO power }(\mathrm{kW})=\frac{2 \pi \mathrm{NT}}{60}
$$

$$
\begin{aligned}
& \mathrm{T}=\text { Torque }(\text { Newton } . \mathrm{m}) \\
& \mathrm{N}=\text { revolution }(\mathrm{rpm})
\end{aligned}
$$

$$
\text { S.f.c. }=\frac{F}{\text { PTO Power }} \times G
$$

S.f.c $=$ Specific fuel consumption $(\mathrm{kg} / \mathrm{kW} . \mathrm{hr})$

F: $\quad$ Fuel specific gravity $\left(\mathrm{kg} / \mathrm{m}^{3}\right)$

The statistical analysis in Table (2) showed the $\mathrm{T}$ test of torque and power for different systems during the PTO test that, there was no significant different between system1 and system 2. Fuel temperature ranged between $45-46{ }^{\circ} \mathrm{C}$, Oil temperature ranged between $95-97^{\circ} \mathrm{C}$ and Cool temperature was $81^{\circ} \mathrm{C}$.

Table (2): The statistical analysis of PTO test for system 1 and system2

\begin{tabular}{|l|c|c|c|c|}
\hline \multirow{2}{*}{} & \multicolumn{2}{|c|}{ SYSTEM 1 } & \multicolumn{2}{c|}{ SYSTEM 2 } \\
\cline { 2 - 5 } & torque (N.m) & power (kW) & torque (N.m) & power (kW) \\
\hline average & 494 & 92 & 496 & 93 \\
\hline No. of reading & 26 & 26 & 26 & 26 \\
\hline Max. value & 635 & 116 & 634 & 118 \\
\hline Median value & 579 & 109 & 579 & 109 \\
\hline Min. value & 0 & 0 & 0 & 0 \\
\hline T cal, & \multicolumn{2}{|c|}{0.98041} & \multicolumn{2}{c|}{0.94194422} \\
\hline T table & \multicolumn{2}{|c|}{2.009} & \multicolumn{2}{c|}{2.009} \\
\hline
\end{tabular}

Fig. $(5,6)$ show the relationship between engine speed , fuel consumption, specific fuel consumption, PTO torque and PTO power for the two systems under study. The maximum value of PTO torque found at low engine speed of (1310and1300 rpm) of 635 and 634 kN.m for system 1 and system 
2 respectively. The maximum value of PTO power found at engine speed of (2041and2036) of 116 and $118 \mathrm{~kW}$ for system 1 and system 2 respectively.

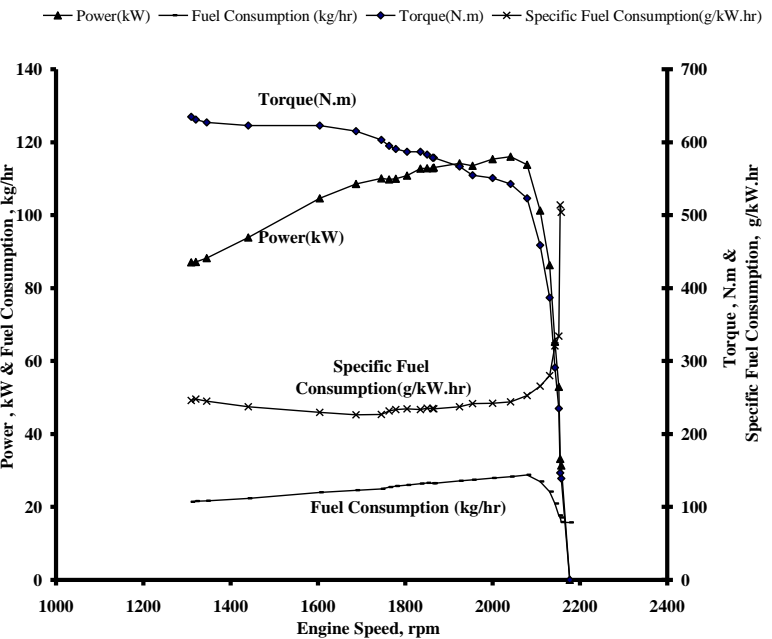

Figure (5): PTO performance of tractor using system1

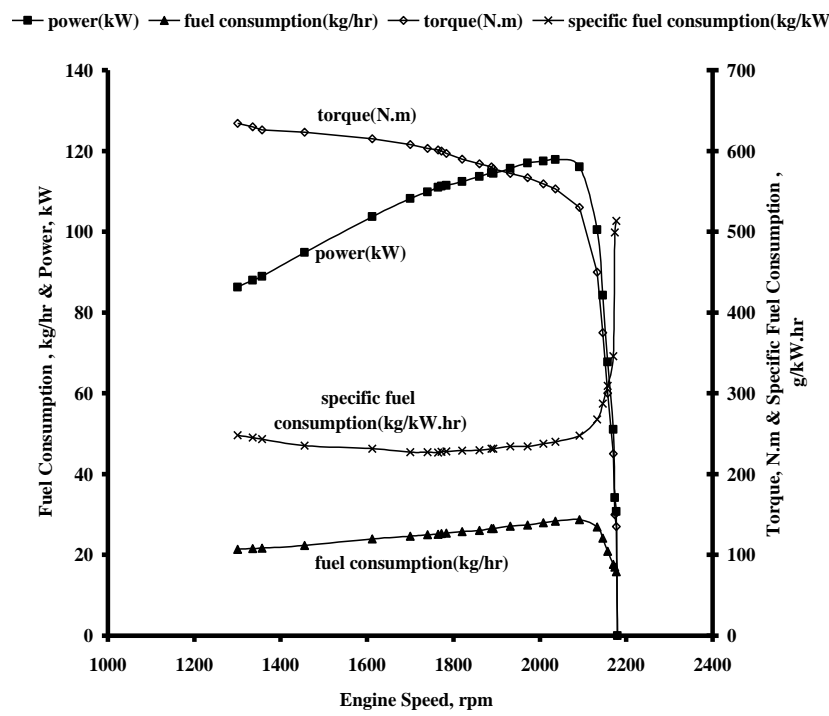

Figure (6): PTO performance of tractor using system2

\section{3- Effect of tractor forward speed on tractor performance:}

The performance of drawbar test has been measured the following data: Forward speed, Fuel consumption $(\mathrm{kg} / \mathrm{hr})$. The calculated data was the drawbar power $(\mathrm{kW})$, equivalent forward speed and Drawbar Pull. Figs (8, and 9) demonstrate the performance of the tractor in drawbar test for 
systems 1 and 2 at two levels of speed (6gears was at low level speed and 3 gears at high level speed). Table (4) showed that the maximum drawbar power affected by drawbar pull using system 1 for gears $\left(6^{\text {th }}\right.$ low gear, $3^{\text {rd }}$ high gear). The maximum value of Drawbar Power found at the lowest drawbar pull of $(33.4$ and $30.3 \mathrm{kN}$ ) of 62.25 and $65.16 \mathrm{~kW}$ and at the highest forward speed of $(6.7$ and $7.75 \mathrm{~km} / \mathrm{hr})$ for system 1 respectively. The minimum value of drawbar power found at highest drawbar pull using system 1 for gears $\left(1^{\text {st }}\right.$ low, $2^{\text {nd }}$ low $)$ of $(50.8$ and $49 \mathrm{kN})$ of 14.59 and $23.95 \mathrm{~kW}$ and at the lowest forward speed of $(1.03$ and $1.76 \mathrm{~km} / \mathrm{hr})$ for system 1 respectively.

Table (4) showed that the maximum drawbar power affected by drawbar pull using system 2 for gears $\left(6^{\text {th }}\right.$ low gear, $3^{\text {rd }}$ high gear). The maximum value of Drawbar Power found at the lowest drawbar pull of (33.5 and $29.1 \mathrm{kN})$ of 62.58 and $62.31 \mathrm{~kW}$ and at the highest forward speed of (6.72 and $7.7 \mathrm{~km} / \mathrm{hr}$ ) for system 2 respectively.

Table (3): the data of drawbar pull measured using improved system1

\begin{tabular}{|c|c|c|c|c|c|c|c|c|c|}
\hline & \multicolumn{6}{|c|}{ Gear low } & \multicolumn{3}{|c|}{ Gear high } \\
\hline & 1st & 2nd & 3rd & 4th & 5th & 6th & 7th & 8th & 9th \\
\hline $\begin{array}{l}\text { Drawbar Pull at max power, } \\
\mathrm{kN}\end{array}$ & 49 & 47.4 & 44.4 & 43.3 & 36.2 & 33.4 & 40.2 & 34.6 & 30.3 \\
\hline $\begin{array}{l}\text { Speed at Max Drawbar } \\
\text { Power, } \mathrm{km} / \mathrm{h}\end{array}$ & 1.77 & 2.31 & 2.94 & 3.89 & 4.91 & 6.7 & 4.84 & 5.77 & 7.75 \\
\hline $\begin{array}{l}\text { Slip at Max Drawbar Power, } \\
\%\end{array}$ & 12.19 & 9.7 & 10.8 & 7.8 & 10.1 & 7.7 & 7.9 & 8.9 & 5.3 \\
\hline Max Drawbar Power, kW & 24.04 & 30.42 & 36.3 & 46.79 & 49.43 & 62.25 & $\begin{array}{c}50.0 \\
5\end{array}$ & 55.45 & 65.16 \\
\hline $\begin{array}{l}\text { Fuel consumption at Max } \\
\text { Drawbar Power, kg/h }\end{array}$ & 18.97 & 18.8 & 18.6 & 17.84 & 18.91 & 18.1 & 18.5 & 19.29 & 17.2 \\
\hline $\begin{array}{l}\text { Specific fuel consumption at } \\
\text { Max Drawbar Power, g/kW.h }\end{array}$ & 0.79 & 0.62 & 0.51 & 0.38 & 0.38 & 0.29 & 0.37 & 0.35 & 0.26 \\
\hline $\begin{array}{lcc}\text { Min } & \text { specific } & \text { fuel } \\
\text { consumption, } \mathrm{g} / \mathrm{kW} . \mathrm{h} & \end{array}$ & 0.75 & 0.6 & 0.5 & 0.38 & 0.37 & 0.28 & 0.37 & 0.34 & 0.26 \\
\hline $\begin{array}{l}\text { Slip at Min specific fuel } \\
\text { consumption, } \%\end{array}$ & 7.78 & 6.7 & 7 & 7.8 & 13.2 & 10.2 & 7.9 & 5.6 & 7.7 \\
\hline $\begin{array}{l}\text { Fuel consumption Min } \\
\text { specific fuel consumption }\end{array}$ & 15.71 & 16.84 & 17.47 & 17.8 & 18.29 & 17.4 & 18.5 & 17.6 & 16.8 \\
\hline $\begin{array}{l}\text { Drawbar Power at Min } \\
\text { specific fuel consumption, } \\
\mathrm{kg} / \mathrm{h}\end{array}$ & 20.8 & 27.78 & 5.0 & 6. & 0 & 61.27 & 50.0 & 51 & 64.69 \\
\hline $\begin{array}{l}\text { Speed at Min specific fuel } \\
\text { consumption, } \mathrm{km} / \mathrm{h}\end{array}$ & 1.85 & 2.39 & 3.11 & 3.89 & 4.74 & 6.52 & 4.84 & 5.99 & 7.56 \\
\hline Drawbar Pull at Min specific & 40.5 & 42 & 40.6 & 43.3 & 37.4 & 33.8 & 40.2 & 31.1 & 30.8 \\
\hline
\end{tabular}




\begin{tabular}{|c|c|c|c|c|c|c|c|c|c|}
\hline \multirow{2}{*}{\multicolumn{10}{|c|}{ fuel consumption, $\mathrm{kN}$}} \\
\hline & & & & & & & & & \\
\hline \multicolumn{10}{|c|}{$\begin{array}{l}\text { Table (4): the data of drawbar pull measu } \\
\text { Gear low }\end{array}$} \\
\hline & $1^{\text {st }}$ & $2^{\text {nd }}$ & $3^{\text {rd }}$ & $4^{\text {th }}$ & $5^{\text {th }}$ & $6^{\text {th }}$ & $7^{\text {th }}$ & $8^{\text {th }}$ & $9^{\text {th }}$ \\
\hline $\begin{array}{l}\text { Drawbar Pull at } \max \\
\text { power, } \mathrm{kN}\end{array}$ & 48.9 & 46.5 & 43.7 & 43.2 & 36.8 & 33.5 & 40 & 34.8 & 29.1 \\
\hline $\begin{array}{l}\text { Speed at Max Drawbar } \\
\text { Power, } \mathrm{km} / \mathrm{h}\end{array}$ & 1.77 & 2.31 & 2.94 & 3.9 & 4.9 & 6.72 & 4.94 & 5.9 & 7.7 \\
\hline $\begin{array}{l}\text { Slip at Max Drawbar } \\
\text { Power, } \%\end{array}$ & 11.83 & 9.44 & 11.99 & 8.42 & 10.61 & 7.94 & 7.8 & 6.76 & 7.8 \\
\hline Max Drawbar Power, kW & 24.05 & 29.8 & 35.67 & 46.84 & 50.09 & 62.58 & 49.84 & 57.09 & 62.31 \\
\hline $\begin{array}{l}\text { Fuel consumption at Max } \\
\text { Drawbar Power, } \mathrm{kg} / \mathrm{h}\end{array}$ & 18.97 & 18.8 & 18.66 & 17.84 & 18.2 & 18.4 & 18.5 & 19.22 & 18.8 \\
\hline $\begin{array}{l}\text { Specific fuel consumption } \\
\text { at Max Drawbar Power, } \\
\text { g/kW.h }\end{array}$ & 0.79 & 0.63 & 0.52 & 0.38 & 0.36 & 0.29 & 0.37 & 0.34 & 0.3 \\
\hline $\begin{array}{l}\text { Min specific fuel } \\
\text { consumption, g/kW.h }\end{array}$ & 0.75 & 0.61 & 0.5 & 0.38 & 0.36 & 0.28 & 0.37 & 0.34 & 0.28 \\
\hline $\begin{array}{l}\text { Slip at Min specific fuel } \\
\text { consumption, } \%\end{array}$ & 7.85 & 6.2 & 5.97 & 8.42 & 10.6 & 10.6 & 7.8 & 4.97 & 13.7 \\
\hline $\begin{array}{l}\text { Fuel consumption Min } \\
\text { specific fuel consumption }\end{array}$ & 15.71 & 16.55 & 16.9 & 17.84 & 18.2 & 17.3 & 18.5 & 18.6 & 16.8 \\
\hline $\begin{array}{l}\text { Drawbar Power at Min } \\
\text { specific fuel consumption, } \\
\mathrm{kg} / \mathrm{h}\end{array}$ & 20.85 & 27.1 & 33.59 & 46.84 & 50.09 & 61.6 & 49.84 & 53.47 & 6.27 \\
\hline $\begin{array}{l}\text { Speed at Min specific fuel } \\
\text { consumption, } \mathrm{km} / \mathrm{h}\end{array}$ & 1.85 & 2.39 & 3.15 & 3.90 & 4.9 & 6.52 & 4.94 & 6.02 & 7.21 \\
\hline $\begin{array}{l}\text { Drawbar Pull at Min } \\
\text { specific fuel consumption, } \\
\mathrm{kN}\end{array}$ & 40.5 & 40.8 & 38.4 & 43.2 & 36.8 & 34 & 40 & 32 & 30 \\
\hline
\end{tabular}

The minimum value of drawbar power found at highest drawbar pull using system 2 for gears ( $1^{\text {st }}$ low, $2^{\text {nd }}$ low $)$ of $(50.8$ and $48.9 \mathrm{kN})$ of 14.46 and $23.94 \mathrm{~kW}$ and at the lowest forward speed of (1.02 and 1.76 $\mathrm{km} / \mathrm{hr}$ )for system 2 respectively.

\section{4- Maximum power and maximum pull}

Table (5) shows the maximum power and maximum pull for system 1 and 2 . Figures 8 and 9 show the data for the two systems. The maximum drawbar power affected by drawbar pull using system 2 and system 1 for gears

( $6^{\text {th }}$ low gear, $3^{\text {rd }}$ high gear). The maximum value of Drawbar Power found at the lowest drawbar pull of (33.5and29.1 kN.m) of 62.58 and $62.31 \mathrm{~kW}$ and at the highest forward speed of (6.72 and $7.7 \mathrm{~km} / \mathrm{hr})$ for 
system 2 and ( 33.4 and $30.3 \mathrm{kN} . \mathrm{m})$ of 62.25 and $65.16 \mathrm{~kW}$ and at the highest forward speed of $(6.7$ and $7.75 \mathrm{~km} / \mathrm{hr})$ for system 1 respectively. The minimum value of drawbar power found at highest drawbar pull using system 2 and system 1 for gears $\left(1^{\text {st }}, 2^{\text {nd }}\right)$. of $(50.8 \mathrm{and} 48.9 \mathrm{kN} . \mathrm{m})$ of

Table (5): Maximum power and Maximum Pull results

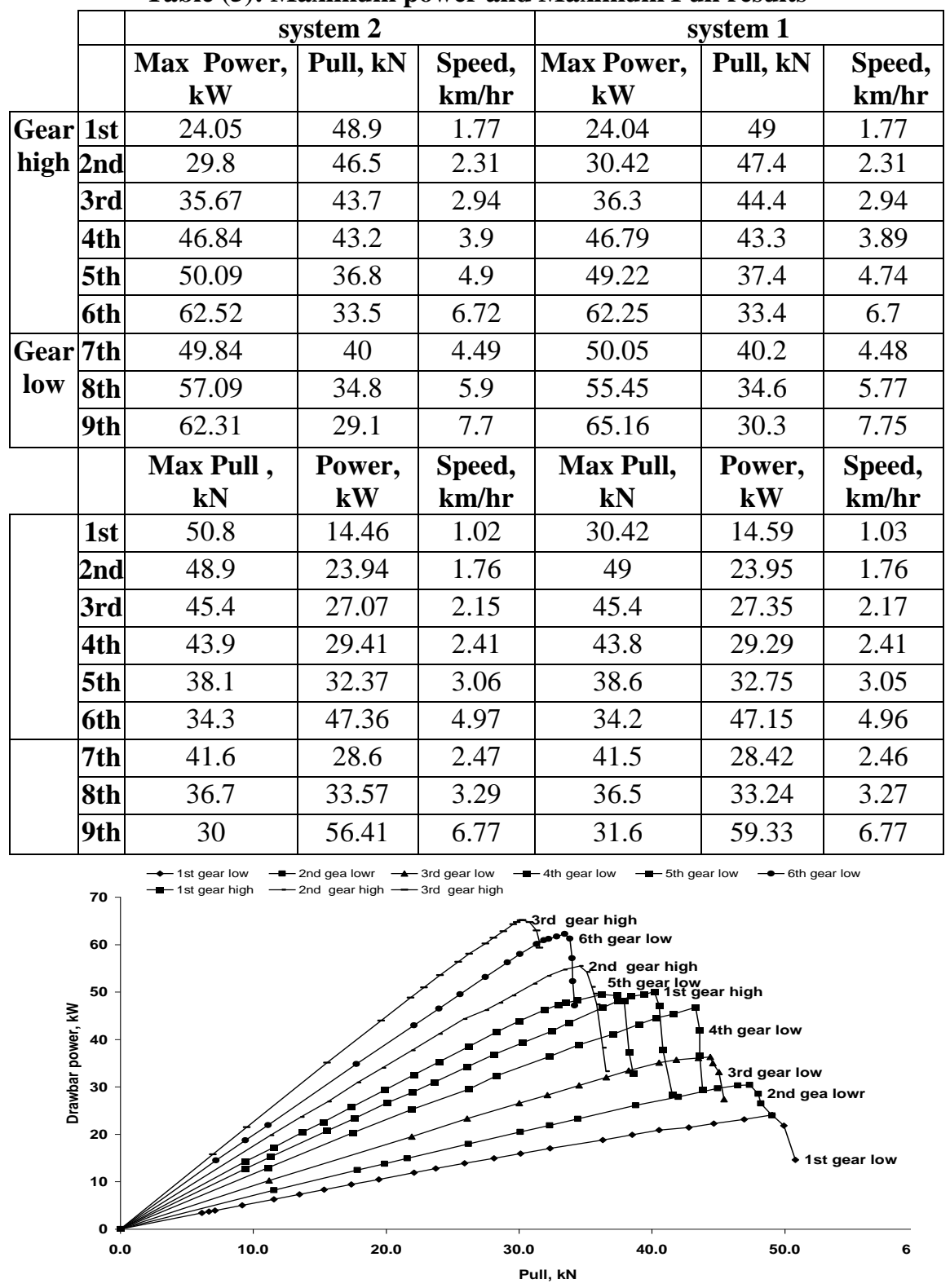

Figure (7): Drawbar power for different tractor gear using system 1. 


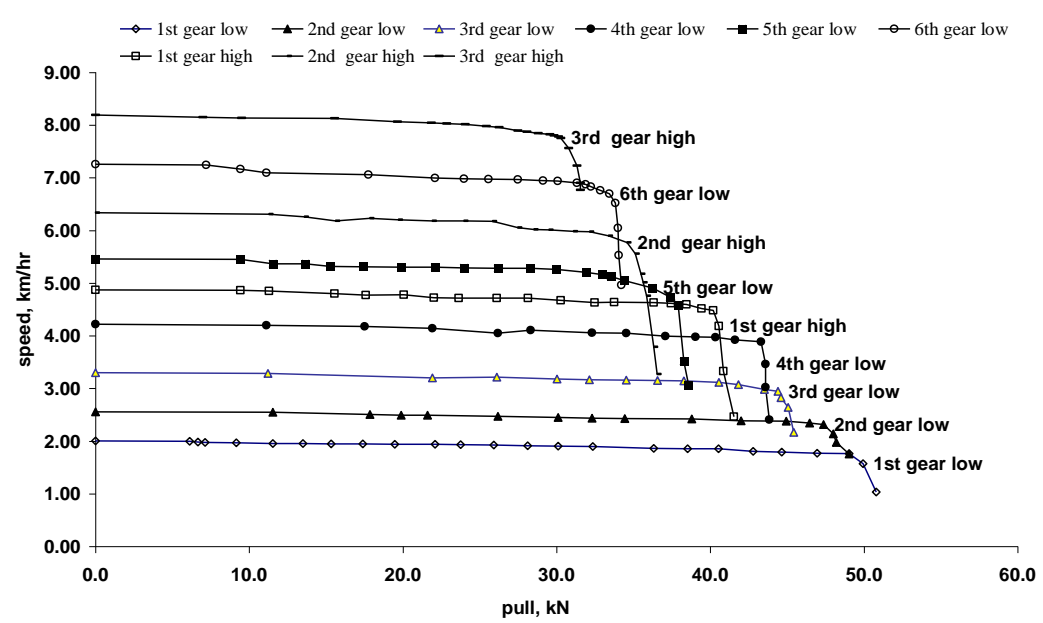

Figure (8): Tractor forward speed recorded by system 1

14.46 and $23.94 \mathrm{~kW}$ and at the lowest forward speed of (1.02 and 1.76 $\mathrm{km} / \mathrm{hr}$ )for system 2 and (50.8 and 49kN.m)of 14.59and $23.95 \mathrm{~kW}$ and at the lowest forward speed of $(1.03$ and $1.76 \mathrm{~km} / \mathrm{hr})$ for system 1 respectively.

\section{CONCLUSION}

- The preliminary data show that no significant between the modified system (system 1) and the system used in tractor test station (system2).

- The modified system is expected to be a worthy one to establish reliable data of the performance parameters of tractors and implements.

\section{REFERENCE}

AL-Janobi, A.; M. F. Wahby and M. A. Al- Belakhy. (1998). A laptop computer based data acquisition system to monitor tractor performance. Misr J. Agric. Eng. 15(3):569-583.

Chen, Y.; N.B. McLaughlin and S. Tessier (2007). Double extended octagonal ring (DEOR) drawbar dynamometer. Soil and Tillage Research, Volume 93, Issue 2, Pages 462-471

Elashry, E. R., A.M. Bassuni, A. A. Sayed Ahmed and K.A.Ahmed. (1994). An instrumentation system for measuring the tractor performance. Misr J. Agric.Eng.11 (4):968-987. 
Elashry, E. R. (2002). Tractive performance for 4-WD tractors under different tire-ballast combinations. Misr J. of Agric. Eng.19 (2):313326.

Elgwadi, A. A. (2005). Manufacturing a local slip ring torque transducer for pto operating implements. Misr J. Agric.Eng.22 (4):497 -508.

Miszczak, M. (2005). A torque evaluation for a rotary subsoiler. Soil and Tillage Research, Volume 84, Issue 2, Pages 175-183.

Mohamed, A. A., A. F. Bahnasy and A. A. Elgwady. (2004). Design and calibration of a device to measure the pulling force of agricultural trailed implements. Misr J. Agric. Eng.21 (2):521-532.

Nada, A. A. (2003). Developing an electronic continuous mass fuel measuring system. The $11^{\text {th }}$ Ann. Conf. Of Misr soc of Agric. Eng.,Oct.:273-282.

Raheman, H . and S.K. Jha . (2007). Wheel slip measurement in 2WD tractor. Journal of Terramechanics, Volume44,Issue1,Pages89-94

Sahu, R.K. and H. Raheman. (2008). A decision support system on matching and field performance prediction of tractor-implement system. Computers and Electronics in Agriculture,Volume60,Issue1,Pages76-86.

\section{الملخص العزبي}
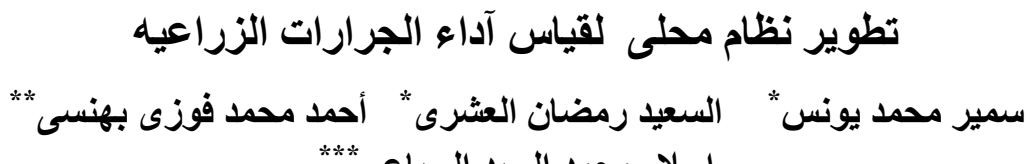
اسلام محمد السيد السباعى **"

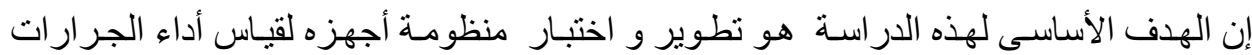

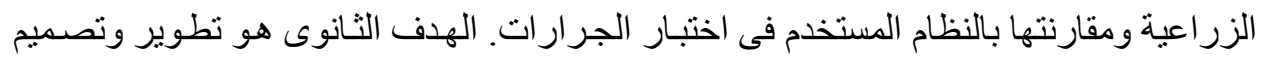

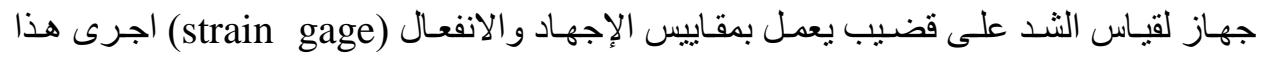

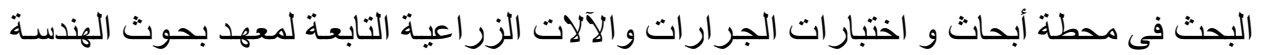

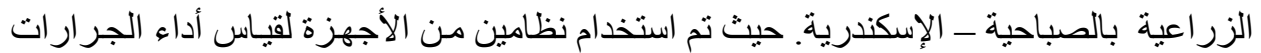

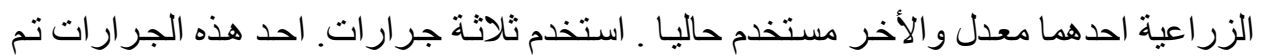

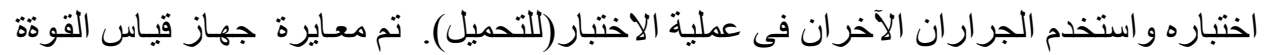

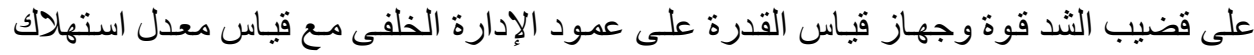

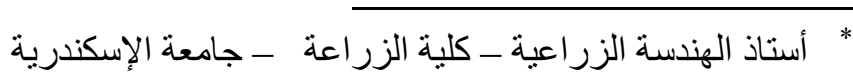

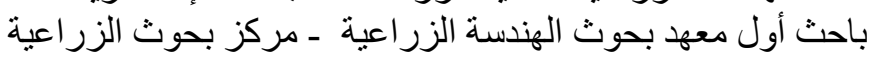

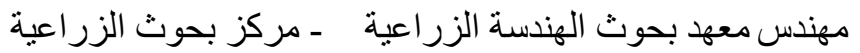


الوقود وقياس عدد لفـات عمود الاداره الخلفى.ووكذلك قياس درجـة حر ارة ميـاه التبريد و الزيت

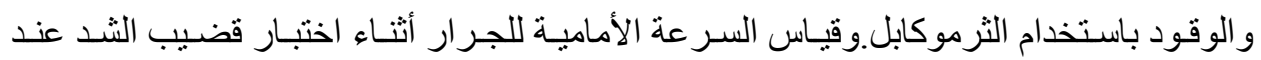

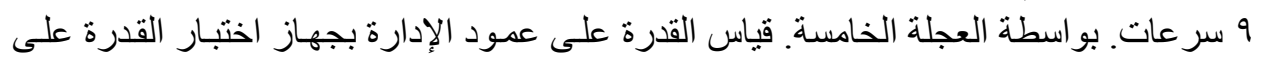
عمود الإدارة الخلفى بو اسطة خلية تحميل ليتناسب مع الاجهزه الالكترونية.

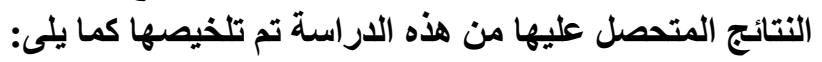

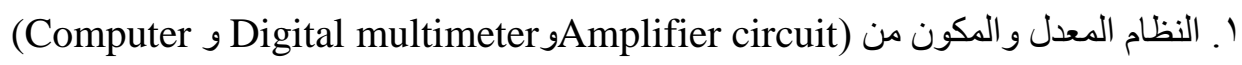
مع جهاز قياس عدد لفات عمود الإدارة الخلفى و جهاز قياس معدل استهلاك الوقود و جهاز

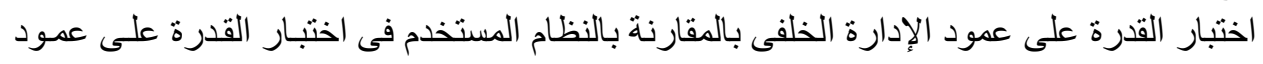

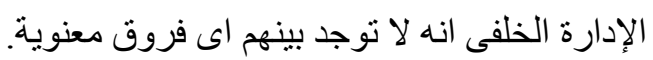

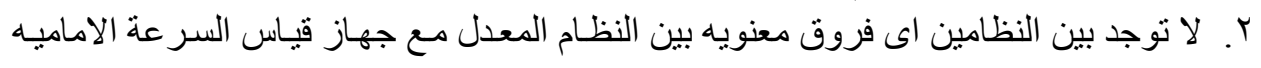

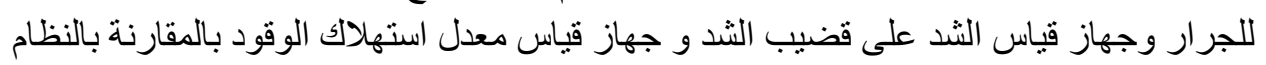

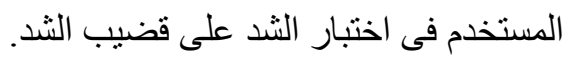

